\title{
UPAYA MENINGKATKAN KECERDASAN KOGNITIF ANAK USIA DINI MELALUI PEMBELAJARAN BERBASIS KOMPUTER PADA KELOMPOK B DI TK AZ ZAITUN BEKASI
}

\author{
Nina Yuminar Priyanti \\ STKIP Panca Sakti Bekasi \\ e-mail: ninanugrah@gmail.com
}

\begin{tabular}{l}
\hline Informasi artikel \\
\hline Received: \\
August 13, 2020. \\
Revised: \\
August 26, 2020. \\
Publish: \\
September 09, 2020.
\end{tabular}

Kata kunci:

Kecerdasan kognitif;

Pembelajaran

Berbasis Komputer;

Anak Usia Dini;

\begin{abstract}
ABSTRAK
Tujuan dari penelitian ini adalah untuk mengetahui peningkatan Kecerdasan Kognitif Anak Usia Dini melalui pembelajaran berbasis komputer pada kelompok B melalui media Paint. Penelitian ini menggunakan model penelitian tindakan kelas (PTK) dengan dua siklus diantaranya setiap siklus terdiri dari empat tahap yaitu perencanaan, pelaksanaan tindakan, observasi, dan refleksi. Subjek penelitian dilakukan pada kelompok B dengan jumlah 15 anak yang terdiri 7 anak laki-laki dan 8 anak perempuan.

Pada penelitian ini, prasiklus yaitu sebelum dilakukan pembelajaran komputer, kemampuan kognitif anak menunjukkan nilai yang rendah yaitu $32 \%$. Namun, setelah dilakukan tindakan pada siklus I persentase anak meningkat sekitar $61 \%$ dan siklus II mengalami peningkatan menunjukan $89 \%$ anak sudah mampu membedakan bentuk geometri Dengan adanya pembelajaran berbasis komputer melalui media Paint ini dapat dijadikan media yang menarik dan menyenangkan dalam meningkatkan kognitif Anak Usia Dini, sehingga dapat menstimulus perkembangan anak serta dapat mengembangkan kemampuan berpikir anak.
\end{abstract}

\begin{tabular}{l} 
ABSTRACT \\
\hline The purpose of this study was to determined the increase of early \\
childhood cognitive intelligence through computer-based learning in \\
group B through paint media. This study used a classroom action \\
research model with two cycles. Each cycle consisting of four stages, \\
there was planning, implementing the action, observing, and reflecting. \\
The subject of this study was group B with a total of 15 children consisting \\
of 7 boys and 8 girls. \\
In this study, pre-cycle used before computer learning was carried out, \\
children's cognitive abilities showed a low value, that was $32 \%$. However, \\
after taking action in cycle I the percentage of children increased by about \\
$61 \%$ and cycle II had an increase, showing that $89 \%$ of children were able \\
to distinguish geometric shapes. \\
Computer-based learning through Paint media can be used as an \\
interesting and fun medium to improve early childhood cognitive. so it \\
can stimulate children's development and develop children's thinking \\
skills.
\end{tabular}

\section{PENDAHULUAN}

Keywords:

Cognitive Ability;

Computer Based

Learning;

Early Chilhood;;

Anak Usia Dini merupakan masa yang optimal pada masa perkembangannya.

Pada masa ini seluruh kemampuan dirinya baik kognitif, fisik motorik, bahasa, sosial emosional dan moral, berkembang sangat pesat. Kemampuan kognitif sangat 
dibutuhkan oleh Anak Usia Dini untuk dapat menstimulus perkembangannya dan untuk dapat mengembangkan daya pikirnya.

Kini dunia pendidikan terus berkembang, perkembangan teknologi ini tidak hanya dirasakan bagi orang tua saja tetapi sudah merambah ke Pendidikan Anak Usia Dini. Anak-anak kini tidak hanya melakukan pembelajaran dikelas saja, mereka pun harus mampu menggunakan teknologi untuk dapat menyesuaikan dengan kondisi jaman yang semakin berkembang.

Berdasarkan hasil observasi awal di TK Az Zaitun kemampuan kognitif anak sangat rendah karena guru masih menggunakan media pembelajaran yang kurang menarik dan tidak bervaiasi. Ini ditunjukkan dari hasil masih rendahnya kemampuan anak dalam membedakan bentuk geometri.

Banyak cara yang bisa dilakukan untuk dapat meningkatkan kognitif anak diantaranya dengan membedakan, menyebutkan dan mengelompokkan bentuk geometri. Ketiga aspek tersebut bisa dilakukan dengan media Paint. Media tersebut dapat dijadikan salah satu media yang efektif dalam perkembangan kognitif anak. Dengan menggabungkan ketiga aspek tersebut diharapkan dapat membantu anak dalam meningkatkan daya pikirnya.

Berdasarkan uraian di atas, peneliti tertarik untuk melakukan penelitian dengan judul Upaya Peningkatan Kecerdasan Kognitif Anak Usia Dini Melalui Pembelajaran Berbasis Komputer pada Kelompok B di TK Az Zaitun, Bekasi

\section{METODE}

Jenis Penelitian pada penelitian ini adalah Penelitian Tindakan kelas (PTK), dengan model tindakan Kemmis dan Mc Taggart yang dijabarkan dalam empat tahap yaitu menurut yaitu: Perencanaan (Planning), Pelaksanaan Tindakan (Acting), Observasi (Observing), Refleksi ( Reflecting). 
Untuk memperoleh data yang valid data dikumpulkan dalam beberapa teknik, yaitu :

1. Observasi (Pengamatan) : Pengumpulan data melalui observasi kemudian peneliti memberikan nilai berupa angka yang telah tersedia, yaitu: 4 (berkembang sangat baik), 3 (berkembang sesuai harapan), 2 (mulai berkembang ), 1 ( belum berkembang ). Observasi dilakukan berkenaan dengan: (a) Kemampuan anak dalam penggunaan media pain (b) kemampuan guru dalam proses belajar mengajar.

2. Unjuk kerja : digunakan untuk menilai tindakan yang digunakan dalam pengumpulan data berbagai informasi kognitif anak. Penilaian dapat dilakukan dengan mengunakan format penilaian kualitatif atau format berskala.

\section{Kriteria Keberhasilan Tindakan}

Tindakan dalam penelitian ini akan dikatakan berhasil jika kemampuan motorik kasar anak mengalami mencapai 75\% dari jumlah anak kelompok B di TK Az Zaitun, Bekasi

\section{Teknik Pengambilan Data}

1. Definisi Konseptual

Pengenalan geometri untuk meningkatkan kognitif anak

2. Definisi Operasional

Definisi operasional merupakan petunjuk tentang bagaimana suatu variabel diukur. Dengan melihat definisi operasional suatu penelitian, maka seorang peneliti akan dapat mengetahui suatu variabel yang akan diteliti.

\begin{tabular}{|l|l|l|}
\hline \multicolumn{1}{|c|}{ Variabel } & \multicolumn{1}{|c|}{ Sub Variabel } & \multicolumn{1}{|c|}{ Indikator } \\
\hline Pengenalan Geometri & $\begin{array}{l}\text { Membedakan bentuk } \\
\text { geometri }\end{array}$ & $\begin{array}{l}\text { Anak dapat membedakan } \\
\text { bentuk }\end{array}$ \\
\cline { 2 - 3 } & $\begin{array}{l}\text { Menyebutkan bentuk } \\
\text { geometri }\end{array}$ & $\begin{array}{l}\text { Anak dapat menyebutkan } \\
\text { perbedaan berdasarkan } \\
\text { bentuk }\end{array}$ \\
\cline { 2 - 3 } & $\begin{array}{l}\text { Pengelompokkkan jenis } \\
\text { geometri }\end{array}$ & $\begin{array}{l}\text { Anak dapat } \\
\text { mengelompokkan jenis } \\
\text { benda }\end{array}$ \\
\hline
\end{tabular}

Tabel 1. Kisi-kisi Instrumen Peningkatan Kognitif Anak 


\section{Keabsahan Data}

\section{Telah Model Tindakan}

Adapun uji keabsahan data dilakukan dengan menggunakan teknik trianggulasi. Trianggulasi dilakukan dengan membandingkan data hasil observasi, catatan lapangan antar pengamat, wawancara, serta studi dokumen.

2. Validasi data

Teknik analisis data yang digunakan dalam penelitian ini adalah analisis penelitian tindakan kelas. Penelitian tindakan kelas digunakan untuk menganalisis data berup angka. Penelitian tindakan kelas dimaksudkan untuk menggambarkan hasil pengamatan peneliti dan kolaborasi dengan guru kelas tentang kemampuan keseimbangan, kekuatan dan kelentukan bertujuan untuk mengetahui peningkatan kemampuan kognitif anak dalam membedakan bentuk geometri.

Adapun perhitungan target pencapaian pembelajaran dapat digunakan rumus Sebagai berikut:

$$
P=\frac{F}{N} \times 100 \%
$$

$\mathrm{P}=$ Prosentase

$\mathrm{F}=$ Frekwensi (dari setiap jawaban angket)

$\mathrm{N}=$ Jumlah siswa

Deskripsikan penilaian diatas sebagai berikut :

1. Berkembang Sangat Baik (BSB) *4 : Anak sudah melakukan/menyelesaikan kegiatan/tugas tanpa bantuan guru secara tepat, cepat, dan benar.

2. Berkembang Sesuai Harapan $(\mathrm{BSH}) * 3$ : anak sudah mampu mengerjakan / melakukan / menyelesaikan kegiatan/ tugas tampa bantuan tetapi belum tepat dan belum benar. 
3. Mulai Berkembang (MB) /*2: Anak belum mampu mengerjakan / melakukan / menyelesaikan kegiatan / tugas dan masih dibantu guru.

4. Belum Berkembang (BB) *1 : Anak belum mau mengerjakan / melakukan/ menyelesaikan kegiatan/tugas. 


\section{PEMBAHASAN}

Pada kondisi awal sebelum diadakan tindakan, peneliti melakukan observasi kegiatan pembelajaran yang dilakukan pada kelompok B diTK Az Zaitun diperoleh kemampaun kognitif anak di kelompok B dengan menggunakan pembelajaran berbasis komputer menunjukkan 32\%. Hasil tersebut masih bisa dikatakan cukup rendah karena belum memenuhi standar. Oleh karena itu dibutuhkan sebuah media yang efektif yang dapat digunakan untuk meningkatkan kognitif anak

Salah satu cara yang dilakukan peneliti untuk dapat meningkatkan kemampuan kognitif anak Usia Dini di $\mathrm{TK}$ Az Zaitun adalah dengan memaksimalkan salah satu media komputer yang akan dilaksanakan didalam pembelajaan yaitu dengan menggunakan aplikasi Paint untuk dapat dijadikan pembelajaran yang efektif dan menyenangkan dengan tetap memperhatikan waktu dan kenyamanan dari anak itu sendiri. Anak dapat melakukan kegiatan mengenal bentuk geometri sesuai dengan arahan dari guru.

Setelah dilakukan tindakan yang dilakukan peneliti pada siklus I dan siklis II dapat ditarik kesimpulan bahwa Pembelajaran komputer yang dilakukan dengan menggunakan Aplikasi Paint yang digunakan untuk meningkatkan kognitif anak di kelompok B di TK Az Zaitun menunjukkan hasil yang lebih baik dari sebelumnya. Hal ini dapat dibuktikan dengaan adanya peningkatan secara signifikan yang terjadi pada kegiatan pengenalan bentuk geometri.

Berdasarkan hasil dari penelitian, mulai dari sebelum dilakukan tindakan dan selama tindakan berlangsung pada siklus I dan siklus II, diperoleh peningkatan pada setiap indikator yang diamati. Siklus I menungnjukan peningkatan dari hasil 
observasi pra siklus yaitu sebesar 61\%. Dan pada siklus II menunjukkan peningkatan sebesar $89 \%$

Tabel Pra Siklus, Siklus I dan Siklus II

\begin{tabular}{|l|l|c|c|c|}
\hline No & Indikator & Pra Siklus & Siklus I & Siklus II \\
\hline 1 & $\begin{array}{l}\text { Anak dapat membedakan bentuk } \\
\text { geometri }\end{array}$ & $32 \%$ & $66 \%$ & $93 \%$ \\
\hline 2 & $\begin{array}{l}\text { Anak dapat menyebutkan } \\
\text { perbedaan bentuk geometri }\end{array}$ & $35 \%$ & $61 \%$ & $88 \%$ \\
\hline 3 & $\begin{array}{l}\text { Anak dapat mengelompokkan } \\
\text { jenis geometri }\end{array}$ & $29 \%$ & $56 \%$ & $86 \%$ \\
\hline 4 & Rata-rata \% & $32 \%$ & $61 \%$ & $89 \%$ \\
\hline
\end{tabular}

Tabel 4. Perbandingan ketercapaian peningkatan kognitif anak

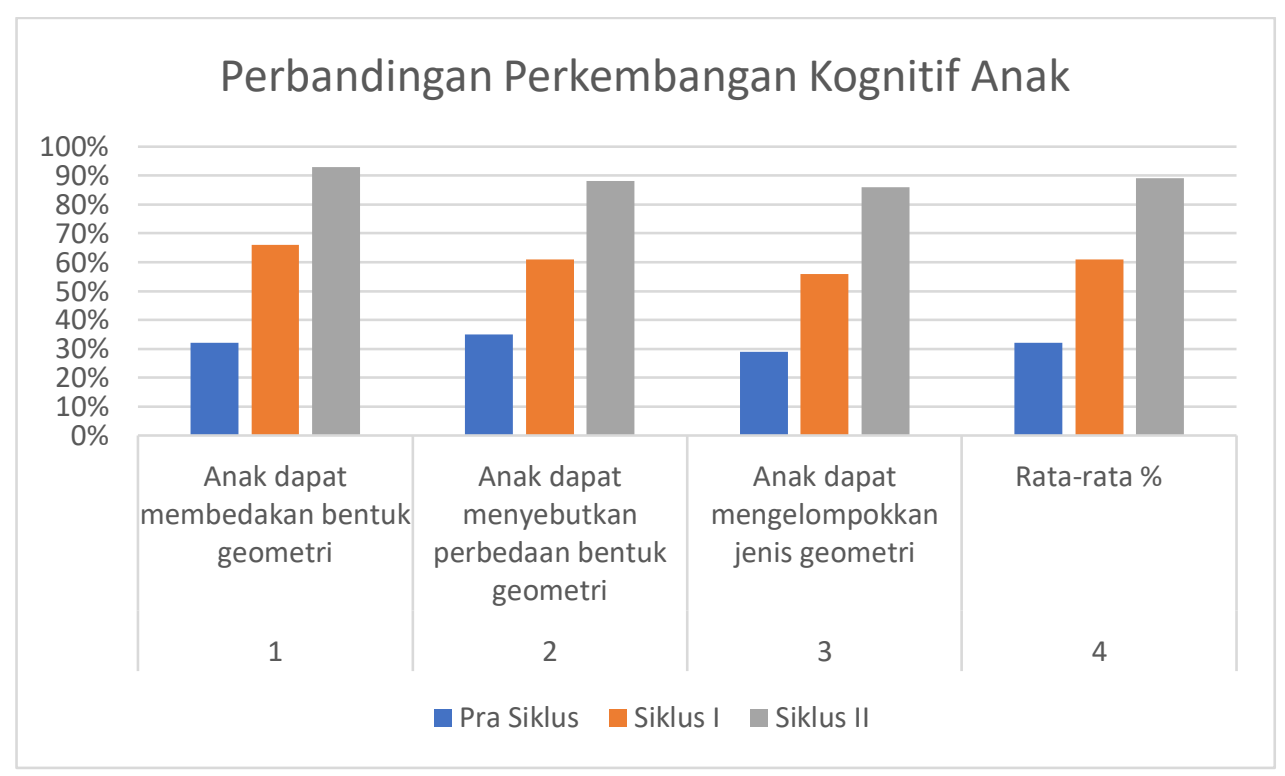

Grafik 3. Perbandingan Perkembangan Kognitif Anak 


\section{KESIMPULAN}

Upaya yang dilakukan untuk dapat meningkatkan kognitif anak di kelompok B di TK Az Zaitun, Bekasi yaitu dengan melakukan pembelajaan komputer dengan menggunakan Aplikasi Paint. Hal ini sesuai dengan hasil akhir dari penelitian yang menunjukkan peningkatan dari siklus I dan siklus II ditandai dengan adanya peningkatan pengenalan geometri anak

Penggunaan pembelajaran komputer dengan menggunakan aplikasi Paint terbukti dapat meningkatkan kognitif anak. Hal ini ditunjukan pada pra siklus sebesar 32\%, kemudian meningkat di siklus I yaitu sebesar $61 \%$ dan naik kembali di siklus II sebesar $89 \%$

\section{SARAN}

Adapun saan yang dapat disampaikan pada penelitian ini adalah sebagai nberikut:

1. Melalui penelitian Upaya Meningkatkan Kecerdasan Kognitif Anak Usia Dini melalui pembelajaran berbasis Komputer diharapkan media pembelajaran ini dapat dijadikan acuan oleh sekolah yang menggunakan progam komputer sebagai salah satu media pembelajaran pada Anak Usia Dini dengan tetap mempertimbangkan efesiensi waktu dan kenyamanan dari anak didik di sekolah masing-masing

2. Sarana dan prasarana yang telah ada dapat manfaatkan semaksimal mungkin guna meningkatkan kualitas pengajaran kepada peserta didik 


\section{REFERENSI}

Arikunto, dkk. (2015). Penelitian tindakan kelas. Jakarta: PT Bumi Aksara.

Arsyad, A. (2003). Media Pembelajaran. Jakarta: PT.Raja Grafindo Persada.

Asmawati (2008). Dasar-dasar Pendidikan Anak Usia Dini Secara Islam, Jakarta: STIT INSIDA

Departemen Pendidikan Nasional (2007). Pedoman Pembelajaran Bidang

Pengembangan Kognitif Di Taman Kanak-kanak. Jakarta: Departemen Pendidikan Nasional.

Hamalik, O. (1994). Media Pendidikan. Bandung: PT.Citra Aditya Bhakti.

Hurlock, B Elizabeth. 1999. Perkembangan Anak Jilid I. Jakarta: Erlangga

Hidayah Nur (2013). Panduan Praktis Penyusunan dan Pelaporan PTK. Jakarta :

Prestasi Pustaka Raya

Khadijah. (2016). Pengembangan Kognitif Anak Usia Dini. Medan: Perdana

Publising.

Munir. (2010). Kurikulum Berbasis Teknologi Informasi Dan Komunikasi.

Bandung: Alfabeta.

Moeslichatoen. (2004). Metode Pengajaran Di Taman Kanak-Kanak. Jakarta: PT

Rineka Cipta.

Sugiyono. (2015). Metode Penelitian Pendidikan. Bandung: Alfabeta.

Suyanto, Slamet. (2005). Dasar-Dasar Pendidikan Anak Usia Dini.Yogyakarta: Hikayat.

Sujiono, Nuaeni, Yuliani (2008), Metode Perkembangan Kognitif. Jakarta : Universitas Terbuka

Susanto, A. (2011). Perkembangan Anak Usia Dini Pengantar Dalam Berbagai Aspek. Jakarta: Kencana

Zaman, Badru. 2011. Media dan Sumber Belajar TK. Jakarta: Universitas Terbuka. 